\title{
Serum GDF-15 Level in Rheumatoid Arthritis and Relation to Disease Activity and Severity
}

M.E.Khalii ${ }^{1}$, M.S.Elhanafy ${ }^{1}$, S.E.Eigela ${ }^{1}$, H.E.Nasr ${ }^{2}$. and M.E.ELgendy ${ }^{3}$

${ }^{1}$ Rheumatology Dept., Faculty of Medicine, Benha Univ., Benha, Egypt

${ }^{2}$ Biochemistry Dept., Faculty of Medicine, Benha Univ., Benha, Egypt

${ }^{3}$ Rehabilitation and Physical,Dept., Faculty of Medicine, Benha Univ., Benha, Egypt

E-Mail: Maryhan213@gmail.com

\begin{abstract}
Growth differentiation factor (GDF)-15 was identified as a factor secreted by activated macrophages which plays an important role in cell growth, signal transduction, and apoptosis regulation. The aim of this study is to: Correlate serum level of growth differentiation factor $15(\mathrm{GDF}-15)$ with disease activity and severity parameters in rheumatoid arthritis patient. This study will include thirty rheumatoid arthritis (RA) patients fulfilling the American College of Rheumatology/European League Against stiffness (ACR/EULAR) criteria to the analysis from claiming RA recruited from Rheumatology, restoration physical and drug outpatient facility What's more inpatient division about Benha school doctor's facilities. Also, twenty solid persons sex Also agdistis matched of the patients were selected in this study as An control bunch. Every last one of patients and controls were subjected with full history taking, full clinical examination, research center investigations that included cbc ,ESR. Crp. Rf, serum -Growth diferentation variable 15(GDF15) levels, those malady movement score -28 (DAS28)was used to assess the infection movement for rheumatiod joint inflammation. The wellbeing evaluation quaestionnaire (HAQ) might have been used to assess those utilitarian status. Those level of joint harm might have been evaluated as stated by Larsen strategy. Clinched alongside our ponder GDF15 levels were fundamentally higher to rheumatiod joint inflammation patients The point when contrasted with those control ( $<<0.05)$. Accordig to pearsons corrrelation, serum GDF15 levels were postivitly associated with esr level,morning firmness. DAS28 score. Youthful joint. Swollen joint,and $\mathrm{x}$ beam "around body of evidence one assembly. GDF15 might assume a part in the pathway from claiming infection action. Joint inclusion large amounts from claiming GDF-15 were connected with sickness activity, level of ESR, morning stiffness, delicate joint count,.
\end{abstract}

Keywords: Rheumatiod arthritis .GDF15..Disease activityscore 28(DAS-28) , Rhematiod factor.CRPMorning stiffness.,Larsen methods.extraarticular manifestation.

\section{Introduction}

Rheumatoid joint inflammation (RA) may be a chronic, systemic, incendiary jumble of obscure etiology portrayed Toward unending aggravation of the synovial joints making profound tissue decimation Previously, influenced joints, joint inflammation representable those major manifestation, Anyway it will be likewise connected with an expanded danger about additional articular difficulties [1].

Aggravated rheumatoid synovium may be portrayed by those presence from securing A large number proinflammatory cytokines, that in the end joint decimation Furthermore repair, joint repair shed might proceed through transforming development factor-b (TGF-b) communicated in the synovium and subsynovial macrophages [2]. In turn TGF-b superfamily, cytokine Growth separation factor(GDF-15) need been embroiled in constant incendiary pathways Previously, rheumatoid joint inflammation. Past investigations bring uncovered that serum levels from claiming GDF-15 were higher in rheumatoid joint inflammation patients Furthermore reflected illness seriousness in any case from claiming excellent sickness markers [3]. Development separation factor(GDF-15) might have been initially distinguished as an element discharged Toward actuated macrophages, What's more assumes a paramount part over cell development What's more differentiation, growth separation factor(GDF-15) statement is for the most part low for resting tissues Anyhow might increment accompanying an versatile anxiety light of different cell division stress indicators for example, hypoxia, inflammation, Also tissue damages [4]. The relationship about macrophage actuation with GDF-15 gene interpretation proposes that GDF-15 might a chance to be a autocrine controller about macrophage actuation [5].

GDF-15 statement will be expanded then afterward incitement Eventually Tom's perusing proinflammatory cytokines, for instance, tumor putrefaction element (TNF)-alpha,interleukin (IL-1) beta, or (IL-6). Notwithstanding that the system from claiming GDF-15 will be not fully elucidated it may be accepted that particularly Previously, inflammation, it could restrain the later periods about macrophage activation, prevent those creation from claiming TNF-a prompted Toward lipopolysaccharides Also also control those part of those proinflammatory cytokine IL-6 [6].

Furthermore GDF-15 impacts the digestion system for carbohydrates What's more lipids. It assumes various parts done Different pathologies for example, such that cardiovascular disease, obesity, inflammation, Also growth because of its mitigating and antiproliferative properties [7].

\section{Aim of the work}

The aim of this study is to Correlate serum level of growth differentiation factor 15 (GDF- 15) with disease activity and severity parameters in rheumatoid arthritis patient.

\section{Subjects and methods}

This examine incorporated fifty people going to over patients What's more out patints centers of 
Rheumatology, restoration Furthermore physical drug outpatient facility Also inpatient Branch for Benha college healing centers. Theydivided under two groups bunch (I): thirty rheumatiod joint inflammation patients satisfying the american school for Rheumatology/European association Against stiffness (ACR/EULAR) criteria for those finding from claiming RA bunch (II): twenty solid persons sex Furthermore agdistis matched of the patients were selected in this study Similarly as An control gathering. Every last one of patients Furthermore controls were subjected should full historical backdrop taking, full clinical examination, lab investigations that included esr. CBC,CRP,RF. Serum levels from claiming GDF15, radiological assessment in the structure about plain X-beam for both hands Also both feet Furthermore At whatever influenced joints.

Criteria to exclusion: Subjects were excluded starting with the study On they needed : period less 18 years, Patients for traumatic arthritis, Rheumatiod joint inflammation tolerant for medicine AntiTNF drug, other rheumatic alternately auto-immune ailment. Moral considerations: An composed agrees were made starting with the sum patients Furthermore control subjects former on investment in the contemplate that might have been affirmed Eventually Tom's perusing moral council of employees for solution. Benha school.

\section{Results}

This study was carried out on three groups:

Group (I): Thirty Rheumatoid Arthritis (RA) patients attending the outpatient clinic and the inpatient unit of the Rheumatology, to the 2010 American College of Rheumatology / European League Against Rheumatism classification criteria for RA (ACR/EULAR) [11]. Their ages ranged between 23 and75years with a mean of $46.13 \pm 13.1$ years. They were $10(33 \%)$ males and $20(67 \%)$ females.

Table (1) Comparison between RA patients and controls groups as regarding age and sex.Comparison between case and control groups

\begin{tabular}{|c|c|c|c|c|c|c|c|}
\hline \multirow[t]{2}{*}{ Variable } & & \multicolumn{2}{|c|}{$\begin{array}{c}\text { Cases } \\
(\text { No.=30) }\end{array}$} & \multirow[t]{2}{*}{$\begin{array}{l}\text { Controls } \\
(\text { No. }=\mathbf{2 0}) \\
\end{array}$} & \multirow{2}{*}{\multicolumn{2}{|c|}{ Test }} & \multirow[t]{2}{*}{$\mathbf{p}$} \\
\hline & & No. & $\%$ & & & & \\
\hline \multirow[t]{2}{*}{ Sex } & Female & 20 & $7 V$ & 9 & $\leqslant 0$ & $\mathrm{X}^{2}=2.31$ & 0.13 \\
\hline & Male & 1. & rr & 11 & 00 & & \\
\hline $\begin{array}{l}\text { Age } \\
\text { (years) }\end{array}$ & $\begin{array}{l}\text { Mean } \pm \mathrm{SD} ; \\
\quad \text { (range) }\end{array}$ & $46.13 \pm 1$ & $3-75)$ & $\begin{array}{c}41.1 \pm 14.1 \\
(22-66)\end{array}$ & & $=1.29$ & 0.20 \\
\hline
\end{tabular}

There were highly statistically significant differences between the studied groups as regarding the mean GDF15 values being higher in the RA patients than in the control group with a mean of $(43.2 \pm 24.65 \mathrm{ng} / \mathrm{ml}), 309.57 \pm 226.96 \mathrm{ng} / \mathrm{ml})$ respectively $(\mathrm{p}<0.001)$.**

Table (2) Comparison between RA patients and controls groups as regarding the mean serum GDF15 levels.

\begin{tabular}{lccccccc}
\hline Study groups & \multicolumn{9}{c}{ GDF15(ng/ml) Media(IQR) } & \multicolumn{1}{c}{$\begin{array}{c}\text { MannWhitny } \\
\text { test (z) }\end{array}$} & P \\
\cline { 2 - 6 } & No. & Mean & \pm SD & Min. & Max. & & \\
\hline RA patients & 30 & 309.57 & 226.96 & 50 & 812 & MW=5.36 & $<0.001^{* *}$ \\
Controls & 20 & 43.2 & 24.65 & 15 & 56 & & \\
\hline
\end{tabular}

$$
\mathbf{p}<\mathbf{0 . 0 0 1} * * \text { = highly significant. }
$$

There were high statistically significant differences among case group as regarding $\operatorname{Rf}(\mathrm{P}<0,05)^{*}$ and highly
GDF15(growth differation factor 15) significant among among case group as regarding $\mathrm{CRP}(<0.001) * *$.

Table (3) GDF-15 differences among case group according to CRP and RF.

\begin{tabular}{llllll}
\hline GDF-15 & No & Median & IQR & Statistical test & P value \\
\hline CRP & & & & & \\
Positive & 23 & 405.0 & $118.0-585.0$ & MW $=2.62$ & $0.009 * *$ \\
Negative & 7 & 80.0 & $62.0-122.0$ & & \\
RF & & & & & \\
Positive & 25 & 385.0 & $108.0-549.0$ & MW $=2.53$ & $0.011^{*}$ \\
Negative & 5 & 80.0 & $59.0-105.0$ & & \\
\hline
\end{tabular}

In the RA patients' group, serum levels GDF15 levels showed statistically highly significant positive correlations with disease durations $(\mathrm{r}=0.506) \quad(\mathrm{p}$ $<0.001)^{* *}$.morning stiffness durations $(\mathrm{r}=0.563)(\mathrm{p}$ 
$<0.001)$,swollen joint count $(\mathrm{r}=0.623)(\mathrm{p}<0.001)$, and there were statistically high significant positive correlation tender joint count $(\mathrm{r}=0.448) \quad(\mathrm{p}<0.001)$ DAS-28 $(\mathrm{r}=0.428) \quad(\mathrm{p}<0.001)$ and HAQ $(\mathrm{r}=-0.439)$ $(\mathrm{p}<0.001)$.

Table (4) Correlation between GDF-15 and clinical variables among case group .

\begin{tabular}{lll}
\hline GDF-15 & rh & P value \\
\hline $\begin{array}{l}\text { Disease } \\
\text { duration }\end{array}$ & 0.506 & $0.004^{*}$ \\
Ms & 0.563 & $0.001^{* *}$ \\
Tender & 0.448 & $0.013^{*}$ \\
joints & & \\
Swollen & 0.623 & $<0.001^{* *}$ \\
joints & & \\
DAS-28 & 0.428 & $0.018^{*}$ \\
HAQ & 0.439 & $0.015^{*}$ \\
\hline
\end{tabular}

In the RA patients' group, serum levels GDF15 levels showed statistically highly significant positive correlations with disease durations $(\mathrm{r}=0.506) \quad(\mathrm{p}$ $<0.001)^{* *}$. .morning stiffness durations $(\mathrm{r}=0.563)(\mathrm{p}$ $<0.001)$, swollen joint count $(\mathrm{r}=0.623)(\mathrm{p}<0.001)$, and there were statistically high significant positive correlation tender joint count $(\mathrm{r}=0.448) \quad(\mathrm{p}<0.001)$ DAS-28 $(\mathrm{r}=0.428)(\mathrm{p}<0.001)$, and HAQ $(\mathrm{r}=-0.439)$ $(\mathrm{p}<0.001))$.

Table (5) Correlation between GDF-15 andESR among case group.

\begin{tabular}{lll}
\hline GDF-15 & rh & P value \\
\hline ESR & 0.391 & $0.033^{*}$ \\
\hline
\end{tabular}

In the RA patients' group, serum levels GDF15 levels showed statistically high significant positive correlation ESR $(r=0.391)(\mathrm{p}<0.05)^{*}$

Table (6) Correlation between GDF-15 and x ray grade among case group.

\begin{tabular}{lll}
\hline GDF-15 & rh & P value \\
\hline $\begin{array}{l}\text { X ray } \\
\text { grade }\end{array}$ & 0.544 & $0.002 * *$ \\
\hline
\end{tabular}

In the RA patients' group, serum levels GDF15 levels showed statistically highly significant positive correlations with $\mathrm{X}$ ray $(\mathrm{r}=0.544)(\mathrm{p}<0.001)^{* *}$.

Table (7) The mean serum gdf15 levels according to the presence of extra articular manifestation in the RA patients' group:

\begin{tabular}{lcccc}
\hline Extra- articular & $\begin{array}{c}\text { Positive group } \\
(\mathbf{1 9 )}\end{array}$ & Negative group (11) & $\begin{array}{c}\text { Statistical } \\
\text { test (MW) }\end{array}$ & P value \\
\cline { 2 - 3 } & Median (IQR) & Median (IQR) & & \\
\hline GDF-15 & $405(183-589)$ & $90(76-231)$ & 2.56 & $0.01 *$ \\
\hline
\end{tabular}

There was high statistically significant difference in the mean serum gdf15 levels according to the presence of extra-articular manifestations between the RA patients' group $(\mathrm{p}<0.05)$.

\section{Discussion}

Our outcomes required demonstrated that the imply serum gdf15 level might have been profoundly essentially lifted in the RA patients' aggregation over the solid subject $(\mathrm{p}<0.001))$. Those imply serum level for gdf15 done RA patients were (43. $2 \pm 24.65 \mathrm{ng} / \mathrm{ml})$, contrasted with $309.57 \pm 226$. 96ng/ml Previously, sound control.

This may be in understanding for (8),(9)- clinched alongside their contemplate serum gdf15 levels went the middle of $(50-812 \mathrm{ng} / \mathrm{ml})$ in the RA patients What's more were Exceptionally essentially lifted over in the control bunch that went between $(15-56 \mathrm{ng} / \mathrm{ml})$.

Comparable with our comes about [10],[7],[3],[2] inferred that serum levels about gdf15were essentially higher in RA patients' assembly contrasted with solid controls and their investigations were Additionally once early RA ailment (duration under 12 months).

The outcomes about our ponder indicated that when the rheumatoid joint inflammation patients were separated under Assemblies as stated by their action grades, we discovered helter skelter huge sure correlations the middle of scores for DAS28 Also serum levels about gdf15 ( $\mathrm{r}=0.428, \mathrm{p}<0.001)$.

These critical certain correlations over serum levels from claiming gdf15 and malady movement as stated by DAS28 clinched alongside RA patients showed for our study were in understanding for. [10] who discovered that serum gdf15 levels were altogether associated for malady movement to RA patients as view scoring for DAS28 (r2 = 0. 407,p=0. 005). [11] show that there were no statistically critical contrasts the middle of mild,moderate ,sever Assemblies for RA Similarly as respect the imply serum level of gdf15and that against our come about.

In our investigation there were statistically huge certain connection with the serum level for gdf15 clinched alongside RA patients Furthermore clinical measures including span of morning stiffness $(\mathrm{r}=0$. $563, \mathrm{p}=0$. 001), number of youthful joints $(\mathrm{r}=0.448, \mathrm{p}=0$. 013), number from claiming swollen joints ( $\mathrm{r}=0.623$. $\mathrm{P}<0.001)$.

These outcomes were in understanding with, [10] who found that there might have been critical connection the middle of serum levels of gdf 15 What's more clinical 
infection movement measures including morning stiffiness, amount for youthful and swollen joints.

To contrast, these effects were not in understanding with [11] discovered that there were no statistically noteworthy relationship the middle of serum level gdf15and clinical ailment action measures including ms, amount of youthful Furthermore swollen joints.

Also done our investigation there were statistically critical certain relationship for those serum level of gdf15 to RA patients and intense period reactant measures including $\operatorname{CRP}(\mathrm{r}=0.503, \mathrm{p}<0 / 001)$ and $\operatorname{ESR}(\mathrm{r}=0.391, \mathrm{p}<0.001)$.

These outcomes were in understanding for [10] who discovered that there might have been noteworthy connection between serum levels from claiming gdf15 and esr fixation.

Clinched alongside our study, the serum GDF15 levels were Exceedingly noteworthy associated for those radiological Larsen $\operatorname{scores}(\mathrm{r}=0.544, \mathrm{p}<0.001)$.

[10] who found no connection the middle of serum levels from claiming GDF15 and the radiological Larsen $\operatorname{scores}(\mathrm{r}=0.130, \mathrm{p}=0.396)$.

In our study, assesmant the RA tolerant around additional articular show fate. We noted there might have been helter skelter statistically critical Contrast in the imply serum GDF15 level as stated by the vicinity about additional articular show fate between those RA patients the middle of serum gdf 15 levels Furthermore additional articular show fate RA patients. $(\mathrm{p}<0.05)$.

These outcomes were in understanding with the examine completed by [10]. there might have been helter skelter statistically critical Contrast over he intend serum GDF15 level as stated by those vicinity of additional articular show fate Concerning illustration cardio vascular malady.

\section{Conclusion}

Our Outcomes indicate the part of gdf15 Concerning illustration an extra device to evaluation about malady action in RA patients particularly with rf certain Also it might be supportive Previously, recognizing patients for more ruinous illness.

So, we might recommended that gdf15 includes will other cytokines a pathogenic part in RA suggesting that focusing on them might make An advantageous restorative method done RA.

\section{Reference}

[1] T.tuncer, A.Kaya, A.Gulkesen, Matrix metalloproteinase-3 levels in relation to disease activity and radiological progression in rheumatoid arthritis. Advances in clinical and experimental medicine: official organ Wroclaw Medical University.), Vol.18,PP.152-156, 2019.
[2] N.S.Breit, H.Johnen, A.Cook, The TGF super family cytokine,MIC/GDF15:apleotrophic cytokine with roles in inflammation,cancer and metabolism.Growth Factor, Vol.29, PP.187-195, 2011.

[3] D.A.Brown, J.Moore, H.Johnen , Serum macrophage inhibitory cytokine 1 in rheumatoid arthritis: a potential marker of erosive joint destruction. Arthritis Rheum , Vol.56, PP.753-756, 2007.

[4] M.Mimeault, S.K.Batra , Divergent molecular mechanisms underlying the pleiotropic function of macrophage inhibitory cytokine-1incancer.J Cell Physiol, Vol.224, PP.626-635, 2010.

[5] A.G.Moore, D.A.Brown, W.D.Fairlie, The transforming growth factor- $\beta$ superfamily cytokine macrophage inhibitory cytokine- 1 is present in high concentrations in the serum of pregnant women. J Clin Endocrinol Metab, Vol.85, PP.4781-4788, 2000.

[6] D.Schlittenhardt, A.Schober, J.Strelau, Involvement of growth differentiation factor-15/macrophage inhibitory cytokine 1 (GDF- 15/MIC-1) in oxLDLinduced apoptosis of human macrophages in vitro and in arteriosclerotic lesions. Cell Tissue Res, vol.318, PP.325-334, 2004.

[7] J.A.Amaya, A.R.Villarraga, N.M. Gozalez, GDF15(MIC1.H6D polymorphism Does Not Influence Cardiovascular Disease in a latin American Population With Rheumatiod Arthritis.J Immunol Res, Vol.72, PP.255-262, 2015.

[8] 8--Kerschan-

Schindl,Katharina,GeroldEbenbichler,:"Rheumatoi $\mathrm{d}$ arthritis in remission." Wiener klinische Wochenschrift, Vol.131(1-2) ,PP.1-7,2019.

[9] Mendoza-Vázquez, Guadalupe, Francisco EspinozaGómez, THU0148 COMPARISON OF SERUM LEVELS OF GDF-15 IN PATIENTS WITH RHEUMATOID ARTHRITIS WITH OR WITHOUT DISEASE ACTIVITY." , Vol.55, PP.347-347, 2019.

[10]O.Tanrıkulu, M.A.Sarıyıldı, I.Batmaz, Serum GDF-15 level in rheumatoid arthritis: relationship with disease activity and subclinical atherosclerosis. Acta reumatologica portuguesa, Vol.55, PP.921-929,2017.

[11] G.Mendoza-Vázquez, F.Espinoza-Gómez, M.Zavala, 2019THU0148 comparison of serum levels of gdf-15 in patients with rheumatoid arthritis with or without disease activity, Vol.5, PP.35-37, 2019. 